\title{
Tugas Polisi dalam Upaya Perlindungan Hak Asasi Manusia dan Penegakan Hukum
}

\author{
DPM Sitompul
}

\begin{abstract}
In the effort of Human Right enforcement always deals with the task of police and law, because Human Right needs law instrument and the enforcement process by the police for granting the existence in the actual life. Without instrument of law, Human Right finds the difficulties in enforcing by the police. And in handling their task, the police must always respects and high appreciates on human right.
\end{abstract}

\section{Pendahuluan}

Pada bulan Januari 1999 marak dan gencar tuntutan akan penghormatan terhadap Hak Asasi Manusia (HAM), yang dideklarasikan sebagai kebutuhan utama dalam rangka eksistensi dan pemajuan umat manusia melekat pada setiap individu. Hak asasi adalah kondrat manusia yang dikaruniakan Tuhan kepada ciptaanNya. Namun dalam penerapannya ada perbedaan tentang konsep HAM, akibat dari perbedaan pendapat budaya, sistem nilai dan norma, tetapi didasari bahwa ada sejumlah kesempatan yang bersifat universal, sehingga sebagian besar negara telah sepakat untuk menyatukan persepsi tentang hal-hal yang bersifat universal tersebut.dan menuangkannya dalam bentuk deklarasi bersama.
Pada saat itu HAM telah berkembang menjadi isu krusial yang tidak hanya berdimensi nasional, melainkan juga internasional. Hal ini berarti bahwa suatu negara tidak dapat lagi mengklaim bahwa persoalan HAM adalah urusan domestik semata-mata, akan tetapi masyarakat internasional berhak pula ikut campur dalam persoalan HAM karena telah diakui oleh masyarakat internasional sebagai suatu yang bersifat universal. ${ }^{1}$

Institusi pemerintah yang wilayah tugasnya kerap dan langsung berkaitan dengan masalah HAM adalah polisi. Pihak militer/tentara biasanya bersentuhan dengan masalah HAM bila sedang terlibat dalam suatu Operasi Militer.

Lingkup tugas kerja polisi berkaitan langsung dengan hidup sehari-hari warga

'B.H Marbun dan Chandra Gatama, HakAsasi Manusia, Penyelenggara Negara yang Baik dan Masyarakat Warga (Jakarta: HAM, 2000), hIm. 141. 
negara. Dari soal "sepele" seperti masalah pelanggaran lalu lintas (lantas) sampai masalah serius menyangkut tindak pidana politik dan korupsi, polisi selalu bersinggungan dengan masalah HAM. ${ }^{2}$

Dalam Undang-undang No.2 Tahun 2002 tentang UU Kepolisian Negara RI, dicantumkan secara tegas masalah HAM di dalam Pasal 14 ayat (1) hurufj dinyatakan bahwa dalam polisi bertugas melindungi keselamatan jiwa raga, harta benda, masyarakat dan lingkungan hidup dari segala gangguan ketertiban, polisi selalu menjunjung tinggi HAM.

Berbicara tentang penegakan HAM maka akan selalu terkait dengan tugas polisi dan hukum. Hal ini dikarenakan HAM membutuhkan sarana hukum dan proses penegakan oleh polisi guna menjamin eksistensinya di dalam hidup nyata. Tanpa sarana hukum, HAM akan sulit diwujudkan dalam penegakannya oleh polisi.

\section{Tugas Polisi dan Kekerasan}

Masalah kekerasan secara yuridis diatur dalam Pasal 89 KUHP, isinya adalah: "yang dikatakan melakukan'kekerasan itu, membuat orang jadi pingsan atau tidak berdaya lagi/ lemah. ${ }^{n}$ Disamakan dengan menggunakan kekerasan". ${ }^{3}$ Pasal 89 KUHP tersebut apabila ditafsirkan lebih jauh dapat dijelaskan bahwa yang dimaksud dengan kekerasan adalah setiap perbuatan dengan penggunaan tenaga badan yang tidak ringan. Tenaga badan adalah kekuatan fisik. Penggunaan kekerasan dengan tangan saja, memukul dengari tongkat, mengikat, menahan dan sebagainya.

Dalam bertugas polisi dapat melakukan kekerasan apabila secara sah diperbolehkan oleh hukum./undang-undang. Dalam banyak kejadian penggunaan kekerasan pada hakekatnya dilakukan apabilakeadaan terpaksa sekali, sehingga penggunaan kekerasan itu tidak dapat dilakukan secara sewenangwenang melainkan dibatasi oleh hukum, sehingga' dapat dikatakan hukum mencegah penggunaan kekerasan yang sewenangwenang. Namun di sisi lain hukum juga membolehkan penggunaan kekerasan oleh polisi apabila dalam keadaan terpaksa sekali, misalnya: diatur dalam Pasal 49 ayat (1) KUHP yang isisnya sebagai berikut: "Barang siapa dalam hal ini polisi yang bertugas melakukan perbuatan yang terpaksa dilakukan untuk mempertahankan dirinya atau diri orang lain, mempertahankan kehormatan atau harta benda sendiri atau kepunyaan orang lain, dari . serangan yang melawan hak dan mengancam dirinya dan segera pada saat itu juga, tidak boleh dihukum".

Penggunaan kekerasan termasuk juga dengan menggunakan senjata api oleh polisi yang pélaksanaannya mempedomni asas legalitas, dan asas kewajiban, serta kewenangan diskresi kepolisian untuk menilai situasi yang dihadapi anggota polisi saat itu.

Hak kewenangan menilai keadaan oleh anggota polisi yang bertugas dan "akan melakukan penembakan" terhadap seorang penjahat, harus mempertimbangkan manfaat serta resiko dari tindakannya itu, demi untuk kepentingan umum (landasan hukum pasal

\footnotetext{
${ }^{2}$ Komnas HAM, Hak Asasi Manusia Membangun Jaringan Kerjasama (Jakarta, Komnas HAM, 1998), hlm. 22.

${ }^{3}$ Moelyanto, Kitab Undang-undang Pidana (Jakarta: Bumi Nusantara, 2001), hlm. 36.
} 
18 ayat (1) dan ayat (2) Undang-undang No. 2 tahun 2002 tentang Kepolisian Negara Republik Indonesia). Sebelum penggunaan senjata api (dalam kerusuhan massa misalnya) lebih dahulu harus dilakukan dengan memberi peringatan teriakan dan anjuran oleh petugas polisi melalui cara:

1. Suara anggota polisi tersebut cukup keras untuk menghentikan aksi si penjahat.

2. Suara tersebut harus jelas dan dapat dimengerti.

3. Kalimatnya harus singkat dan jelas.

4. Peringatan dengan suara tersebut harus dengan sikap yang sungguh-sungguh.

Setelah dengan tindakan dengan seruan teriakan peringatan tersebut dilakukan maka dapat dilakukan tembakan peringatan ke atas 3 kali. Apabila masih belum dapat diatasi situasinya, diberikan tembakan terarah dibawah pinggang dengan peluru karet untuk melumpuhkan. Jika membahayakan jiwa masyarakat/petugas ditembakkan senjata api dengan peluru tajam untuk melumpuhkan dengan sasaran pinggang ke bawah. Uruturutan tindakan tersebut di atas diberlakukan polisi apabila menghadapi pelaku kerusuhan yang membahayakan keselamatan jiwa petugas/masyarakat, merusak tempat ibadah/ fasilitas umum/kantor pemerintahan dan Markas TNI/melakukan penjarahan massal.

Penggunaan kekerasan dengan senjata api dilaksanakan tidak boleh sembarangan tetapi dengan sasaran yang jelas. Dengan kriteria tepat waktu, tepat situasi, tepat sasaran dan tepat prosedur, secara internasional ada ketentuan yang mengatur tentang penggunaan kekerasan dan senjata api oleh aparat penegak hukum, ketentuan tersebut antara lain: (1) Kode Etik untuk para pejabat penegak hukum yang tèlah disahkan oleh Resolusi
Majelis Umum PBB tanggal 17 Desember 1979. dalam pasal 3 ditegaskan bahwaa: para pejabat penegak hukum (polisi) dapat menggunakan kekerasan hanya apabila sangat perlu dan sebatas dibutuhkan untuk pelaksanaan tugas mereka. Pengertian pasal ini mengandung 3 hal, yaitu:

a. Bahwa para pejabat penegak hukum (polisi) dapat diberi wewenang untuk menggunakan kekerasan hanya apabila perlu menurut keadilan untuk mencegah kejahatan, atau dalam melaksanakan penagkapan yang sah terhadap pelaku kejahatan yang dicurugai pelaku kejahatan.

b. Sesurai atas keseimbangan antara pengguna kekerasan dengan tujuan yang hendak dicapai.

c. Peläku kejahatan memberi perlawanan dengan senjata api atau membahayakan jiwa orang lain.

d. Tind̦akan-tindakan lain yang kurang ekstrim tidak efektif lahi.

(2) Konggres. VII PBB tanggal 27 Agustus -2 September 1990 di Hanava Cuba, telah mensahkan prinsip-prinsip penggunaan kekerasan dan senjata oleh para pejabat penegak hukum (polisi). Penggunaan senjata api diatur dalam pasal 9 yang intinya adalah bahwa penggunaan senjata api dapat dilakukan dalam hal: (a) untuk membela diri atau membela orang. lain terhadap ancaman kematiar ätau luka parah yang segera terjadi. (b) untuk mencegah dilakukannya suatu tindakan kejahatan yang sangat serius. (c) untuk mencegah pelaku kejahatan melarikan diri dan apabila cara yang kurang ekstrim tidak cukup untuk mencapai tujuan-tujuan ini.

Dalam prinsip dasar tersebut juga diatur tentang bagaimana sikap penegak hukum (polisi) dalam menjaga ketertiban per- 
himpunan yang tidak sah namun nonkekerasan (aksi damai) namun menghadapi perhimpunan keras (brutal). Menghadapi aksi damai, kekerasan dibatasi sekecil mungkin. Untuk menghadapi massa brutal, senjata api dapat digunakan bila caralsarana yang kurang membahayakan tidak dapat digunakan dalam kondisi seperti di Pasal 9 Konvensi Hanava tahun 1990.

\section{HAM dalam Beberapa Hukum Positif Indonesia}

\section{Undang-Undang Dasar 1945}

Undang-Undang Dasar 1945 dalam penjelasannya menyebutkan bahwa "Negara Indonesiaberdasarkan atas hukum (Reshtstaat), tidak berdasarkan atas kekuasaan belaka (Machtstaat). Bila dicermati keseluruhan gagasan, pemikiran jiwa dan semangat teks Undang-Undang Dasar 1945, mulai pembukaan, batang tubuh sampai penjelasannya serta perkembangan pemahaman kita terhadap hal-hal yang mendasar dalam bentuk kehidupan berbangsa dan bernegara, maka pengertian negara hukum yang kita miliki ternyata mengandung makna yang luas dan mendalam, yang memuat prinsip-prinsip tertib hukum, serta kesadaran untuk menjunjung tinggi hukum prinsip-prinsip tersebut, bilamana diterapkan dengan sungguhsungguh, maka akan mencakup tidak saja segi legalitas tindakan negara/pemerintahan, dengan adanya peradilan yang bebas tetapi juga mencakup penghargaan dan perlindungan hak-hak asasi manusia.

Oleh karena itu setiap penegakan hukum haruslah diartikan tidak saja untuk mewujudkan kepastian hukum dan keadilan tetapi juga termasuk didalamnya tujuan kepastian hukum dan keadilan tetapi juga termasuk didalamnya tujuan perlindungan HAM. Di dalam UUD 1945 pasal-pasal yang berhubungan dengan HAM bisa disarikan antara lain: hak untuk menentúkan nasib sendiri (preambule), hak akan warga negara (Pasal 26), hak akan kesamaan dan persamaan di depan hukum (Pasal 27), hak untuk bekerja (Pasal 27), hak untuk hidup layak (Pasal 27), hak asasi manusia Pasal 28 A sampai Pasal $28 \mathrm{~J}$. Pasal $28 \mathrm{~g}$ UUD 1945: (1) Setiap orang berhak atas perlindungan diri pribadi, keluraga kehormatan, martabat, dan harta benda yang di bawah kekuasaannya, serta berhak atas rasa aman dan perlindungan dari ancaman ketakutan untuk berbuat atau tidak berbuat sesuatu yang merupakan hak asasi. (2) Setiap orang berhak untuk bebas daripenyiksaan atau perlakuanyang merendahkan derajat martabat manusia dan berhak memperoleh suaka politik dari negara lain.

Pasal 28 I UUD 1945: (1) Hak untuk hidup, hak untuk tidak disiksa, hak untuk kemerdekaan pikiran dan hati nurani, hak beraagama, hak untuk tidak diperbudak, hak untuk diakui sebagai pribadi di hadapan hukum, dan hak untuk tidak dituntut atas dasar hukum yang berlaku surut adalah hak asasi manusia yang tidak dapat dikurangi dalam keadaan apapun; (2) setiap orang berhak bebas dari perlakuan yang bersifat diskriminatif atas dasar apapun dan berhak mendapatkan perlindungan terhadap perlakuan yang bersifat diskriminatif itu; (3) identitas budaya dan hak masyarakat tradisional dihormati selaras dengan perkembangan zaman dan perbedaan.

Hak beragama (Pasal 29), hak untuk membela negara (Pasal 30), hak akan pendidikan (Pasal 31), hak akan kesejahteraan sosial (Pasal 33), hak akan jaminan sosial 
(Pasal 34), hak akan kebebasan dan kemandirian peradilan (penjelasan Pasal 24 dan 25), hak mempertahankan tradisi budaya (penjelasan Pasal 32), dan hak mempertahankan Bahasa Daerah (penjelasan Pasa! 31).

\section{Undang-undang No.39 Tahun 1999 tentang Hak Asasi Manusia}

Dalam Undang-undang tentang Hak Asasi Manusia No. 39 Tahun 1999 diatur tentang masalah hak mengembangkan diri (Pasal 11 sampai Pasal 16), hak memperoleh keadilan (Pasal 17 sampai Pasal 19), hak atas kebebasan pribadi (Pasal 20 sampai Pasal 27), hak atas rasa aman (Pasal 28 sampai Pasal 35), hak atas kesejahteraan (Pasal 36 sampai Pasal 42), hak turut serta dalam pemerintahan (Pasal 42 sampai Pasal 44), hak wanita (Pasal 45 sampai Pasal 51), hak anak (Pasal 52 sampai Pasal 66).Disamping itu diatur juga tentang masalah pengadilan hak asasi manusia yang berat dibentuk pengadilan hak asasi manusia dilingkungan peradilan umum (Pasal 104).

\section{Undang-undang No. 26 Tahun 2000 Tentang Pengadilan Hak Asasi Manusia}

Dalam undang-undang tersebut diatur ketentuan-ketentuan antara lain tentang jenis pelanggaran hak asasi manusia yang berat yaitu kejahatan genosida dan kejahatan terhadap manusia (Pasal 7 sampai Pasal 9). Hukum acara dari pengadilan hak asasi manusia diatur mulai Pasal 10 sampai Pasal 33, yang mengatur tentang tata cara penangkapan, penahanan, penyelidikan, penyidikan, penuntutan, dan pemeriksaan di sidang pengadilan. Pengadilan hak asasi manusia tersebut pada tahun 2002 populer di Indonesia antara lain karena disidangkannya kasus pelanggaran HAM berat yang terjadi di TimorTimur pada bulan Maret 2002, di pengadilan Jakarta Pusat.

\section{Undang-undang Kepolisian Negara Republik Indonesia No.2 Tahun 2002}

Undang-undang Kepolisian Negara Republik Indonesia No.2 Tahun 2002, secara tegas mencantumkan di dalam beberapa pasalnya tentang hak asasi manusia yang berkaitan dengan tugas polisi, misalnya dalam Pasal 4,14 ayat (1), 16 ayat (2), 19 ayat (1) bahkan dalam konsideran menimbang huruf b Undang-undang No.2 tahun 20002 tersebut dicantumkan tentang menjunjung tinggi hak asasi manusia:

"Bahwa pemeliharaan keamanan dalam negeri melalui upaya penyelenggaraan fungsi Kepolisian yang meliputi pemeliharaan keamanan dan ketertiban masyarakat, penegakan hukum, perlindungan, pengayoman dan pelayanan kepada masyarakat dilakukan oleh Kepolisian Negara Republik Indonesia selaku alat Negara yang dibantu oleh masyarakat dengan menjunjung tinggi hak asasi manusia."

Dari sisi konsideran menimbang Undangundang No. 2 Tahun 2002 tentang Kepolisian Negara Republik Indonesia tersebut di atas, dapat dilihat bahwa pemeliharaan keamanan dalam negeri melalui Kamtibmas, upaya penegakan hukum, upaya perlindungan, pengayoman dan pelayanan masyarakat yang selalu menjunjung tinggi hak asasi manusia. 


\section{KUHAP}

KUHAP bukanlah produk yang sempurna, tetapi secara umum bisa disebut bahwa KUHAP telah memberikan dasar-dasar hukum prosedural yang komprehensif bagi perlindungan HAM, seperti perlindungan terhadap tersangka, antara lain: hak untuk diperlakukan tidak bersalah, hak akan bantuan hukum, hak untuk tidak ditahan semena-mena, hak untuk tidak disiksa dan dianiaya, hak akan pra peradilan dan sebagainya.

\section{Beberapa Pelanggaran HAM}

1. Pelanggaran HAM dalam Rangka Perlindungan HAM

Dalam melaksanakan tugas penegak hukum dapat terjadi polisi melaksakakan pelanggaran HAM yang sebenarnya harus ditegakkan. Selama pelaksanaan tugas penegakan hukum berdasarkan ketentuan hukum, maka hilanglah sifat pelanggaran hukum misalnya: tugas Polisi dalam menangkap, menahahan, menggeledah, memborgol dan sebagainya. Semua itu dilakukan berdasarkan kewenangan berdasarkan hukum (Kitab Undang-Undang Hukum Acara Pidana) sehingga anggota Polisi tersebut tidak dianggap melanggar HAM.

\section{Tindakan Kekerasan yang Melanggar HAM}

Dalam hal tertentu, tindakan kekerasan dibenarkan oleh konvensi HAM, yaitu Pasal 29 Deklarasi Umum HAM, untuk menjamin HAM orang lain, moral, ketertiban dan keselamatan umum yang harus ditetapkan oleh UndangUndang. Tetapi kita harus akui juga, bahwa dalam praktek penegakan hukum Polisi sering melakukan tindakan kekerasan yang tidak sesuai dengan Pasal 29 Deklarasi Umum HAM.

Misalnya tindakan kekerasan oleh Polisi dalam rangka mengejar pengakuan, mendapatkan informasi atau kadang-kadang karena emosional petugas yang sangat bersemangat menegakkan HAM masyarakat, lalu melupakan hak asasi tersangka. Tindakan kekerasan oleh Polisi yang juga sering kita dengar dan lihat, adalah tindakan kekerasan terhadap pelaku kejahatan, dengan kata lain tersangka tidak lagi membahayakan kepentingan umum, karena sudah tertangkap, tetapi masih ada tindakan kekerasan main hakim sendiri oleh Polisi yang melanggar HAM, tindakan tèrsebut tidak kita tolerir/salah.

\section{Pelanggaran HAM oleh Masyarakat}

Tindakan kekerasan yang melanggar HAM bukan hanya memonopoli aparat (Kepolisian), tetapi juga dilakukan oleh anggota masyarakat lainnya, seperti penganiayaan, pembunuhan, penghinaan, pemerkosaan, dan jenis-jenis kejahatan lainnya yang mengganggu hak-hak asasi manusia di bidang hak hidup, hak milik, hak kehormatan.

Hal-hal tersebut menimbulkan pemikiran bagi kita, bahwa pengertian dan pemahaman tentang HAM, harus dipahami secara baik oleh setiap anggota masyarakat, agar masyarakat tersebut mengerti akan hak-haknya, juga respon ternhadap hak-hak asasi orang-orang.

4. Pelanggaran Masyarakat Terhadap Hukum

(a) Perusakan sarana hukum. Dari berbagai sarana dan prasarana hukum, yang paling menonjol adalah perusakan markas kesatuan Polri, tidak sedikit kerusakan yang diderita 
sejumlah markas komando Polri diberbagai wilayah. (b) Serangan terhadap aparat penegak hukum. Selain merusak sarana Polri, juga ada tindakan kekerasan oleh masyarakat yang ditujukan kepada personel Polri, yang' mengakibatkan nyawa anggota Polri.

\section{Tugas POLRI dalam Upaya Perlindungan HAM dan Penegakan Hukum}

\section{Tugas Polri Dalam Perlindungan HAM}

Krisis yang dialami oleh masyarakat indonesia dewasa ini telah mengungkapkan suatu kenyataan bahwa: pada saat Orde Baru memerintah kondisi hak asasi manusia di Indonesia masih rapuh. Kondisi ini dapat diamati dari sikap dan perilaku pihak-pihak penguasa tertentu yang melanggar hak asasi manusia, yang mengakibatkan kesengsaraan hidup dan rasa takut yang meluas, terutama bagi rakyat miskin dan berbagai kelompok minoritas sosial dan minoritas politik:

Masalah yang mendasar saat itu adalah: (1) demokrasi di Indonesia belum memberdayakan rakyat dalam kedaulatannya untuk dapatmengkoreksi arah pelaksanaan kebijakan pemerintah. (2) Penegakan hukum di Indonesia dalam bahaya karena lebih menjadi alat kekuasaan sehingga tidak responsif lagi. Akibatnya supremasi hukum tidak dapat ditegakkan. (3) Ketidak adilan sosial dewasa ini telah mencapai tingkat kesenjangn disegala bidang yang tidak dapat lagi ditolerir oleh masyarakat.

Masih rapuhnya kondisi hak asasi manusia disebabkan oleh karena dahulunya meluas gejala kesewenang-wenangan dan dominasi kekuasaan oleh sebagian penyelenggara Negara. Akibatnya rakyat terintimidasi secara berkelanjutan sehingga tidak berani menyatakan hak-haknya secara wajar. Kondisi hidup seperti ini mudah menyulut sikap dan tindak kekerasan oleh berbagai pihak.

Anjuran-anjuran retorik untuk menyalurkn tuntutan atas hak-haknya melalui institusiinstitusi yang ada, baik hukum maupun politik, saat itu sulit terlaksana karena sebagian besar rakyat dibuat tidak berdaya. Sedangkan yang berani menyampaikan rasa keprihatinannya secara damai masih dicurigai, sehingga sering tidak memperoleh pelayanan yang baik.

Saat Orde Reformasi, kondisi hak asasi manusia pun lebih baik, namun masih mencerminkan kerapuhan-kerapuhan, walaupun diakui bahwa jauh lebih baik ketimbang masa orde baru memerintah Indonesia.

Tanpa mengingkari telah tercapainya berbagai kemajuan perlindungan hak asasi manusia, kondisi hak asasi manusia dewasa ini masih cenderung perlu diadakan perbaikan. Keadaan ini hanya dapat diatasi bila diadakan reformasi ekonomi, politik dan hukum dengan segera dan serentak disegala bidang kehidupan bermasyarakat, berbangsa dan bernegara. Disamping itu perlu antipasi rakyat dengan sungguh-sungguh diperhatikan dan ditindaklanjuti oleh pemerintah.

Kita perlu menyiasati peran aparat penegak hukum (Polisi) dalam negara demokrasi dan dalam masyarakat yang demokratis, yang juga merupakan konsep pokok dari konvensi tentang hak asasi manusia. Adalah sangat bodoh kalau kita mengira bahwa aparat penegak hukum (Polisi) dianggap sẹbagai musuh utama hak asasi manusia. 
Sebagai insan dan manusiayang berusaha keras, para penegak hukum (Polisi) mempunyai kemampuan untuk berbuat baik dan buruk. Seperti halnya negara dan kekuasaan negara, para penegak hukum (Polisi) dan kekuasaan penegak hukum dapat menjadi pelindung maupun pelanggar hak asasi manusia. Secara jujur, kalau kita harus menjawab apakah para penegak hukum itu (Polisi) sebagai pelindung atau pelanggar hak asasi manusia tiada seorangpun yang mampu menjawabnya secara tepat dan mudah. P. Lauprecht dalam tulisannya yang berjudul The Council Of Erope: Democracy, Rule of Law and Human Right di halaman 16, menulis: "If We are honest, we have to recognise that there can ofcourse be a tension between respect for human right and the axigencies (keadaan darurat) of law enforcement. There is tension between order and librerty; not only the level of philosophical and moral debate but also in daily conduct of our lines. There is not point in denying the existence of this tension and political conflict. A society without conflic is a fiction of totalitarian regimes."

Di kalangan para penegak hukum (polisi) diseluruh dunia dikenal ensential principles on human rights, antara lain:

1. International human rights law is binding on all states and their agents, including law enforcement officials. Hukum hak asasi manusia internasional mengikat semua negara peserta seluruh aparatnya, termasuk para penegak hukum.

2. Human rights are legitimate subject for international law, and for international security. Hak asasi manusia disahkan sebagai subjek hukum internasional dan untuk dilakukan pemeriksaan yang cermat secara internasional.

3. law enforcement officials are abliged to know, and to apply, international standards on human rights. Para pejabat penegak hukum (polisi) berkewajiban untuk mengetahui dan melaksanakan standar internasional hak asasi manusia.

Para penegak hukum (Polisi) harus mempunyai budaya yaitu budaya penegak hukum (law enforcement culture). Para penegak hukum (Polisi) harus mempelajari bagaimana caranya bergaul dengan berbagai macam komunitas dan minoritas. Para penegak hukum harus juga dekat dengan penduduk apapun asal usulnya. Para penegak hukum (Polisi) harus mempunyai "muka", jangan tanpa "muka".

Aktualisasi tugas polisi sebagai penegak hukum, antara lain harus mampu melakukan hal-hal sebagai berikut:

1. Menguasai dan mahir dalam hukum pidana, acara pidana, maupun hukum perdata sehingga mampu menghadapi setiap permasalahan hukum pidana atau hukum perdata dengan tepat, dapat mengetahuinya dan dapat mengatasi pra peradilan.

2. Menguasai teknik dan taktik penyelidikan serta penyidikan sehingga mampu membuat terang dan terungkapnya setiap tindak pidana yang terjadi, dan dalam tindakannya selalu menjunjkung tinggi hak asasi manusia.

3. mempunyai semangat dan tekat yang kuat untuk menjadi "Crimer Hunter" dengan motto walaupun esok langit akan runtuh

${ }^{4}$ Koesparmono Irsan, Hak Asasi Manusia dan Hukum (Jakarta: PTIK, 2002), him. 194-197. 
hukum haruis ditegakkan".

4. mampu memanfaatkan kemajuan ilmu pengetahuan dan teknologi guna membantu mengungkap pembuktian secara ilmiah kejahatan yang terjadi, demi untuk menegakkan hak asasi manusia.

5. mampu mengkoordinasikan dengan segenap instansi terkait dalam penegakan hukum pada sistem peradilan pidana, khususnya mengkoordinasikan dan mengawasi penyidik pegawai negeri sipil, untuk melindungi hak asasi manusia.

Dalam melaksanakan tugas-tugasnya Polisi diberi kesempatan untuk bertindak menurut penilaiannya sendiri "membuat diskresi kepolisian". Diskresi kepolisian tersebut dapat ditemukan dasar hukumnya dalam Pasal 18 ayat (1) Undang-undang No. 2 Tahun 2002 tentang Kepolisian Negara Rl, yang intinya sebagai berikut: "Untuk kepentingan umum pejabat Kepolisian Negara RI dalam melaksanakan tugas dan wewenangnya dapat bertindak menurut penilaiannya sendiri".

Rumusan kewenangan Kepolisian Negara Republik Indonesia dalam Pasal 18 ayat (1) Undang-undang Nomor 2 Tahun 2002 merupakan kewenangan yang bersumber dari asas kewajiban umum Kepolisian (Plichtmatigheids beginsel) yaitu suatu azas yang memberikan kewenangan kepada pejabat kepolisian untuk bertindak atau tidak bertindak menurut penilaiannya sendiri, dalam rangka kewajibannya menjaga, memelihara ketertiban dan menjamin keamanan umum.

Secara umum, kewenangn ini dikenal sebagai "diskresi kepolisian" yang absahnya didasarkan pada pertimbangan keperluannya untuk tugas kewajiban (Pelicthmssiges Ermessen).
Pembahasan substansi Pasal 18 ayat (1) Undang-undangan Nomor 2 Tahun 2002 ini cukup panjang karena substansi ini merupakan konsep kewenangan kepolisian yang baru diperkenalkan walaupun di dalam kenyataan pelaksanaan tugas kepolisian sehari-hari selalu dipergunakan.

Seorang petugas kepolisian negara Republik Indonesia yang bertugas ditengahtengah masyarakat seorang diri, harus mampu mengambil keputusan berdasarkan penilaiannya sendiri apabila terjadi gangguan terhadap ketertiban dan keamanan umum atau bila diperkirakan akan timbul bahaya bagi ketertiban dan keamanan umum. Dalam keadaan seperti itu tidak mungkin baginya untuk meminta pengarahan terlebih dahulu dari ataśannya sehingga dia harus berani memutuskan sendiri tindakannya. Tindakan kekhawatiran bahwa si petugas tersebut akan bertindak sewenang-wenang akan sangat tergantung kepada kemampuan subyektif dari si petugas tersebut.

Untuk itu, dalam ilmu hukum Kepolisian dikenal beberapa persyaratan yang harus dipenuhi apabila seorang petugas kepolisian akan melakukan tugasnya dengan membuat "Deskresi" yaitu:

1. Tindakan harus "benar-benar diperlukan (noodzakelijk, notwendig) atau ass keperluan.

2. Tindakan yang diambil harus benar-benar untuk kepentingan tugas kepolisian (zakelljk, sachlich).

3. Tindakan yang paling tepat untuk mencapai sasaran yaitu hilangnya suatu gangguan atau tidak terjadinya sesuatu yang dikhawatirkan. Dalam hal ini yang diapaki sebagai ukuran yaitu tercapainya tujuan (zweckmassig, doelmatig). 
4. Asas keseimbangan (evenredig). Dalam mengambil tindakan, harus senantiasa dijaga keseimbangan antara sifat (keras lunaknya) tindakan atau sarana yang dipergunakan dengan besar kecilnya suatu gangguan atauberat ringannya suatu obyek yang harus ditindak.

Suatu gangguan ketertiban yang kecil tidak perlu ditiadakan dengan tindakan yang membuat orang-orang disekitarnya menjadi panik. Sebaliknya apabila suatu tindakan lunak dan persuasif tidak mampu menghilangkan gangguan ketertiban yang dihadapi, seorang petugas kepolisian harus memutuskan untuk mengambil tindakan lain yang lebih sesuai dengan tingkatan dari sifat gangguan yang dihadapinya.

Dalam mengambil tindakan berdasarkan penilaian sendiri yang paling menentukan kualitas tindakan adalah kemampuan dan pengalaman petugas kepolisian yang mengambil tindakan tersebut.

Oleh karena itu, pemahaman tentang "Dikresi Kepolisian" dalam Pasal 18 ayat (1) harus dikaitkan juga dengan konsekuensi pembinaan profesi yang diatur dalam Pasal 31,32 , dan 33 Undang-undang Nomor 2 tahun 2002 sehingga terlihat adanya jaminan bahwa petugas Kepolisian Negara Republik Indonesia akan mampu mengambil tindakan secara tepat dan profesional berdasarkan penilaiannya sendiri dalam rangka pelaksanaan tugasnya. Pelaksanaan ketentuan sebagaimana dimaksud dalam ayat (1) hanya dapat dilakukan dalam keadaan yang sangat perlu dengan memperhatikan peraturan perundangundangan, serta Kode Etik Profesi Kepolisian Negara Republik Indonesia.
Rumusan dalam Pasal 18 ayat (2) merupakan rambu-rambu bagi pelaksanaan "Diskresi" sebagaimana dimaksud pada ayat (1) yaitu selain asas keperluan, tindakan diskresi tetap harus sesuai dan memperhatikan peraturan perundang-undangan serta Kode Etik Profesi Kepolisian Negara Republik Indonesia. ${ }^{5}$

Tugas Polisi dalam Menegakkan Hukum Sekaligus Melindungi HAM

Adanya 15 (lima belas) prinsip-prinsip HAM dalam UUD 1945 jelas merupakan "Prime Factie Efidense" dari komitmen negara ini terhadap HAM, namun bisa juga dilihat sebagai possesion paradox dalam artian memiliki HAM tetapi belum sepenuhnya menikmati HAM karena cenderung lemahnya rasa hormat terhadap HAM.

HAM diatur dalam Undang-Undang No. 2 Tahun 2002 tentang Kepolisian Negara Republik Indonesia Pasal 4: "Kepolisian Negara'Republik Indonesia bertujuan untuk mewujudkan keamanan dalam negeri yang meliputi terpeliharanya keamanan dan ketertiban masyarakat, tertib dan tegaknya hukum, terselenggaranya perlindungan, pengayoman dan pelayanan kepada masyarakat, serta terbinanya ketentraman masyarakat dengan menjunjung tinggi hak asasi manusia".

Pasal 14 ayat (1) Undang-Undang No. 2 Tahun 2002 tentang Kepolisian Negara Republik Indonesia menegaskan: "Dalam melaksanakan tugas pokok sebagaimana dimaksud dalam Pasal 13, Kepolisian Negara Republik Indonesia bertugas: "huruf I:

${ }^{5}$ Momo Kelana, Memahami Undang-Undang Kepolisian (Jaḳarta, PTIK-Press. 2002), hlm. 111-113. 
'Melindungi keselamatan jiwa raga, harta benda, masyarakat, dan lingkungan hidup daral gangguan ketertiban dan/atau bencana termasuk memberi bantuan dan pertolongan dengan menjunjung tinggi hak asasi manusiaa".

Pasal 16 ayat (2) Undang-Undang No. 2 Tahun 2002 tentang Kepolisian Negara Republik Indonesia: "Tindakan lain sebagaimana dimaksud dalam ayat (1) huruf I adalah tindakan penyelidikan dan penyidikan yang dilaksanakan jika memenuhi syarat sebagai berikut: "huruf e:'menghormati hak sasi manusia".

Pasal 19.ayat (1) Undang-Undang No. 2 Tahun 2002 tentang Kepolisian Negara Republik Indonesia: Dalam melaksanakan tugas dan wewenangnya pejabat Kepolisian Negara Republik Indonesia senantiasa bertindak berdasarkan norma hukum dan mengindahkan norma agama, kesopanan, kesusilaan, serta menjunjung tinggi hak asasi manusia".

Dari beberapa penjelasan tentang isi pasal-pasal dalam Undang-Undang Kepolisian R.I tersebut di atas dapat dilihat bahwa masalah HAM, secara tegas dicantumkan dalam isi Pasal-Pasal 14, 16, dan' Pasal 19 ayat (1), yang berarti dalam melaksanakan tugasnya Polisi harus selalu menghormati HAM dan menjunjung tinggi hak asasi manusia.

Dalam kaitannya dengan tugas Polisi di Pasal 14, 16 dan Pasal 19 ayat (1) UndangUndang No. 2 Tahun 2002 tersebut di atas dalam melakukan pemeriksaan pendahuluan, (untuk menegakkan hukum) para penyidik Polisi, harus melindungi dan memperhatikan hak asasi manusia dari para tersangka seperti tercantum dalam Pasal-pasal Hukum Acar Pidana tersebut di bawah ini:

1. Hak untuk segera diperiksa, diajukan ke
Pengadilan dan diadili (Pasal 50 ayat (1), (2) dan (3) KUHAP).

2. Hak untuk mengetahui dengan jelas dan bahasa yang dimengerti olehnya tentang apa yang disangkakan dan apa yang didakwakan (Pasal 51 butir a dan b KUHAP).

3. Hak untuk memberikan ketrangan secara bebas kepada penyidik dan Hakim seperti tersebut di muka (Pasal 52 KUHAP)

4. Hak untuk mendapat juru bahasa (Pasal 53 ayat (1) KUHAP).

5. Hak: untuk mendapat bantuan hukum pada setiap tingkat pemeriksaan (Pasal 54 KUHAP).

6. Hak untuk mendapatkan nasehat hukum dari penasehat hukum yang ditunjuk oleh pejabat yang bersangkutan pada semua tingkat pemeriksaaan bagi tersangka atau terdakwa yang diancam pidana mati dengan biaya cuma-cuma.

7. Hak tersangka ataui terdakwa yang berkebangsaaan asing untuk menghubungi dan berbicara dengan perwakilan Negaranya (Pasal 57 ayat 6t (2) KUHAP).

8. Hak untuk menghubungi Dokter bagi tersangka atau terdakwa yang ditahan (Pasal 58 KUHAP).

9. Hak untuk diberi tahu kepada keluarganya atau' orang lain yang serumah dengan tersangka atau terdakwa yang ditahan untuk mendapatkan bantuan hukum atau jaminan bagi penangguhannya dan hak untuk berhubungan dengan keluarga maksud yang sama dengan di atas (Pasal 59 dan Pasal 60 KUHAP).

10. Hak untuk dikunjungi șanak'keluarga yang tidak ada hubungan dengan perkara tersangka atau terdakwa. Untuk kepentingan pekerjaan atau kepentingan 
kekeluargaan (Pasal 61 KUHAP).

11. Hak tersangka atau terdakwa untuk berhubungan surat menyurat dengan penasehat hukumnya (Pasal 62 KUHAP).

12. Hak tersangka atau terdakwa untuk menghubungi dan menerima kunjungan rohaniawan (Pasal 63 KUHAP).

13. Hak tersangka atau terdakwa untuk mengajukan saksi dan ahli yang a de charge (Pasal 65 KUHAP).

14. Hak tersangka atau terdakwa untuk menuntut ganti kerugian (Pasal 68 KUHAP).

Selain hal tersebut di atas, masih ada beberapa hak-hal tersangka atau terdakwa lainnya, seperti di bidang penahanan, penggeledahan, dan lain-lain, yang tidak diuraikan dalam tulisan ini.

Dari beberapa hak tersangka tersebut di atas dapat ditarik kesimpulan bahwa pemeriksaan pendahuluan (Vooronderzoek) yang dilakukan oleh penyidik terhadap tersangka boleh didampingi oleh penasehat hukum dan penasehat hukumnya dapat mengikuti jalannya pemeriksaan secara pasif, secara pasif maksudnyya Penasehat hukumnya mengikuti jalannya pemeriksaan dengan cara melihat serta mendengar kecuali dalam hal kejahatan terhadap keamanan Negara penasehat hukum tersebut hanya boleh melihat tapi tidak mendengar. ${ }^{6}$

\section{Hambatan Perlindungan HAM dalam Praktek Penegakan Hukum}

\section{a. Budaya Paternalistik}

Budaya paternalistik masih hidup dan melekat pạda sebagian besar masyarakay kita, khususniya di kalangan masyarakat pedesaan, hal-hal yang diucapkan oleh pemimpin formal maupun informal walaupun terkadang pernyataan itu tidak sesuai dengan HAM, namun karena diucapkan oleh pemimpin karismatik, lalu dianggap sebagai suatu kebenaran atau walaupun dalam hati kecilnya menolak namun tidak berani mengungkapkan hak dan perasaannya, hak dan pemikiran, sehingga menghambat pelaksanaan hak asasinya.

\section{b. Kesadaran Hukum yang Rendah}

Kesadaran hukum yang masih rendah mengakibatkan keengganan masyarakat untuk melaporkan adanya pelanggaran HAM disekitarnya, terutama karena tidak ingin mencampuri urusan orang lain, keengganan menjadi saksi atau tidak ingin repot karena urusan orang lain. Dalam hal-hal tertentu keengganan (tidak mau) menjadi saksi ini menyulitkan Polri dalam mengungkap kasuskasus kejahatan yang terjadi, sehingga Polri lalu cenderung untuk mengejar pengakuan tersangka, karena kadang upaya-upaya mengejar pengakuan tersangka dilakukan dengan tindakan-tindakan kekerasan.

\section{c. Budaya Loyalitas}

Sikap loyalitas ini juga hidup subur diseluruh lapisan masyarakat, di sisi lain loyalitas mengandung konotasi negatif yakni kepatuhan/kesetiaan yang berlebihan terhadap perintah atau petunjuk pimpinannya baik dalam sụatu organisasi resmi maupun pimpinan organisasi non formal. Seharusnya

${ }^{6}$ Hutadjulu, PH, Polisi dan Hak Asasi Manusia dalam KUHAP (Surabaya: CV. Sibaya, 1999), hlm. 24-25 
yang kita kembangkan adalah budaya komitmen terhadap tugas, tanggung jawab, HAM dan masyarakat, dalam arti harus ada keberanian anggota masyarakat untuk menentang perintah pimpinannya, apabila pimpinannya tersebut tidak sesuai dengan aturan hukum, moral, ketertiban dan keamanan dan terutama tidak sesual dengan HAM.

\section{d. Kesenjangan}

\section{Teori Hukum dan Praktek Hukum}

Walaupun teori hukum dan hukum-hukum tertulis yang kita miliki belum sempurna, namun sebenarnya dengan aturan-aturan yang ada pelanggaran HAM seharusnya sudah dapat diminimalkan. Tetapi dalam praktek terlihat bahwa belum tentu aturan-aturan yang baik itu lalu dalam pelaksanaannya juga baik. Manusia-manusia pelaksanan dalam hal ini kadang-kadang masih terlihat tidak sepenuhnya mengaplikasikan secara tepat dan benar atuiran-aturan tersebut.

\section{Sosialisasi Hukum}

Masalah hukum, khususnya sosialisasi hukum kepada seluruh lapisan masyarakat belum menggembirakan, atau belum gencar dilaksanakan, seperti sosialisasi keluarga berencana atau sosialisasi HAM. Kiranya sosialisasi menjadi renungan kita bersama agar seluruh lapisan masyarakat mengerti dan memahami hak-hak asasinya dan menghormati hak-hak asasi orang lain.

\section{Pembangunan Hukum}

Pembangunan bidang-bidang hukum, seperti aturan hukum, aparatur hukum, sarana prasaranan, budaya hukum, juga belum mencapai sasaran yang dilinginkan, sarana dan prasarana hukum masih kurang, budaya hukum yang belum melembaga serta kelemahan-kelemahan unsur-unsur hukum lainnyä, belum mendukung sepenuhnya upaya pemajuan dan perlindungan HAM.

\section{Interaksi Dalam Pemajuan dan Perlindungan HAM \\ Kendala yang bersumber kepada} lingkungan kondisi geografis, kondisi penduduk dikaitkan dengan perbandingannya dengan jumlah posisi, dan masyarakat yang disiplin nasionalnya masih rendah serta cenderung memilih jalan pintas menyelesaikan masalah-masalah hukum, berpengaruh dalam penegakan hukum yang kita harapkan.

Kendala lain yang bersumber dari dalam Polri sendiri antara lain; adalah dibidang pendidikan sumber daya manusia, anggaran pelaksana tugas penegakan hukum materiil dan fasilitas serta berbagai kendala lainnya yang tidak mudah diatasi/diselesaikan dalam jangka pendek.

Dari segi yuridis nampak antara lain; tumpang tindihnya hukum acara pidana, ketidak pastian dan rekayasa penerapan hukum, konsistensi pelaksanaan hukum serta kecenderungan pembuatan undang-undang yang kurang mengacu kepada kepentingan umum, melainkan untuk kepentingan golongan atau organisasi sektor masih teruș berlangsung.

\section{Simpulan}

Masalah hukum dan HAM bukan hanya terbatas pada pengertian dan pemahaman, jauh lebih penting dari itu adalah tata nilai perilaku masyarakat dan aparat yang mencerminkan hukum dan HAM untuk sampai pada tahap perilaku, barang kali bukan barang 
yang mudah, diperlukan kerja keras kita semua yang perlu kontinu dan dalam jangka panjang untuk dapat merubah perilaku dan budaya yang telah berakar dan dapat bertentangan dengan hukum dan HAM.

Tanpa hukum positif yang memberikan sanksi terhadap pelanggaran HAM dan adanya parameter HAM yang digunakan dalam rangka pelaksanaan penegakan hukum yang tercantum dalam suatu peraturan perundang-undangan bersifat legal formal, maka penegakan HAM akan hanya terbatas angan-angan, karena sifat dan wajah HAM yang sangat komplek sering menimbulkan kerancuan dalam penafsiran oleh berbagai pihak.

Peran mahasiswa dewasa ini demikian berarti dan penting di dalam setiap usaha mendobrak dinding yang menghambat gerakan masyarakat menuju masyarakat yang demokrasi karena itu disarankan kemampuan dan kekuatan dalam menggerakkan pemajuan dan perlindungan HAM, hendaknya dioptimalkan baik dalam rangka sosialisasii, merealisasi hak asasi terutama menghargai hak-hak asasi sesama komponen bangsa, oleh para mahasiswa.

Yang paling menentukan adalah hati nurani kita, disarankan hendaknya segala tindakan kita ukur dengan kata nurani dalam arti kata dialog dalam pribadi kita menjadi filter perbuatan dan tingkah laku sebagai anak bangsa yang merasa bertanggung jawab akan kemajuan negeri tercinta ini.o

\section{Daftar Pustaka}

Baldwin, Robert dan Richard 'Kinsey, Police Powers dan Politics, London: Quarted Books Limited, 1982.

Bayley, David H, Police For The Future, New York: Oxford University Press Inc, 1994.

Djamin, Awaloedin, Administrasi Kepolisian RI, Bandung: Sanyata Sumanasa Wira, Sespim Polri, 1995.

Hutadjulu, PH, Polisi dan Hak Asasi Manusia dlam KUHAP, Bandung: CV. Sibaya, 1999.

Irsan, Koesparmono, Hak Asasi Manusia dan Hukum, Jakarta: PTIK, 2002.

Komnas HAM, Hak Asasi Manusia, Tanggun Jawab Negara, Peran Institusi Nasional dan Msyarakat, 1999.

_- Hak Asasi Manusia dalam Perspektif Budaya Indonesia, Jakarta: PT. Gramedia Pustaka Utama, 1997.

, Hak Asasi dalam Tajuk, Jakarta: Institut Ecata, 1997.

, Hạk Asasi Manusia, Jakarta: 1998.

Kelana, Momo, Memahami Undang-Undang Kepolisian, Jakarta: Grafira Indonesia, 2002. 
Rahardjo, Satjipto dan Anton Tabah, Polisi Vermande, 1986.

Pelaku dan Pemikir, Jakarta: PT. Gramedia Pustaka Utama, 1993.

Souryal, Sam S, Ethics In Criminal Justice, Texas: Hamsville, 1998.

Thibault, Edwward A, Lawrence M, Lynch dan R: Bruce M.C Bride, Proaktive Police Management, New Jersey: PrenticeHall, Ino 1998.

Sulliva, John L, Introduction to Police Science Villiers, Peter, Better Police Ethlcs, London:

Sabadan, dan Kunarto, Kejahatan Berdimensi Bramshill, 1974.

Baru, Jakarta: PR. Cipta Manunggal, 1999.

Paul De.Jong, Het Blauwe Recht, Koniklijke
P. Lauprecht, The Council Of Erope: Democracy, Rule of Law and Human Right, 1997.

EOEOE 